\title{
The Pattern of Clientelism in Lampung Local Election
}

\author{
ROBI CAHYADI KURNIAWAN \\ Social and Political Science Faculty, University of Lampung \\ email: robicahyadi9@gmail.com
}

\begin{abstract}
Clientelism is a renewal of the concept of patronage, a patron of clients commonly referred to in several scientific studies. This research uses a qualitative method through an in-depth interview approach to informants and literature studies. The results show that clientelism among voters occurred in the election of Bandar Lampung Mayor Election in 2015. There is a symbiosis of mutualism between incumbent candidates for the Mayor and voters. Voters are influenced by their choices through imaging, giving, programs, and profitable policies. Voters benefit from education policies, free health, infrastructure and social assistance. Another pattern is shown in Lampung Governor Election 2014 when Sugar Group Company (SGC), with their significant power position and influence in sugar trade, fully supports the nomination of M. Ridho Ficardo. The pattern used is by holding entertainment shows and puppets with various attractive prizes offered such as motorbikes, refrigerators, and farm animals. Many voters are interested in giving their votes and get the prizes in return.
\end{abstract}

Keywords: the pattern, clientelism, regional election

\section{Introduction}

The relationship between voters and candidates in a series of regional head elections has always been an interesting thing to learn in the field of political science studies. Research on the relationship between voters and regional head candidates in Indonesian more often discusses about voter behavior, political participation, and campaign methods. Whereas, research on money politics, vote buying, and patronage and clientelism are quite rare.

Direct local elections since decentralization in 2005 had a negative and positive impact. The positive impact was the emergence of voter enthusiasm for the new method of direct election that was different from the previous one applied in new order regime. Enthusiasm was correlated with high rates of voter participation in local elections within the initial five years of 20052010. Unfortunately, in the following year, enthusiasm declined, votes were traded and the symptoms of patron clients emerged in the election.

One of the negative impacts of the direct regional head elections, according to Aspinal and Sukmajati (2015) who conducted research on 2014 legislative elections, is that legislative elections became arena for exchanging interests and circulating money and/or goods as facilitators to get votes. Legislative elections in 2014 were considered as the elections with big money in politics. There were political brokers, the third parties in elections, which had increasingly strong and influential roles as a bridge between candidates and voters (Aspinall \& Sukmajati, 2015: 2-10).

The Lampung governor and legislative elections in April 2014 was interesting to be used as material for this research because the time was close to the general legislative elections, so that there could be a similar political phenomenon. In practice, the Lampung Governor election became a battleground for political, economic and social and cultural interests in Lampung.

The direct election of regional head volume one in Lampung Province in November 2015 was interesting to be analyzed because there were eight regencies and cities celebrated the democracy. Bandar Lampung became an interesting case of representative because it was thought to have a strong pattern of clientelism on Herman HN's absolute victory. 
The researcher attempted to examine the possibility of a patron-client phenomenon of local politics in 2014 Governor of Lampung election. It was getting interesting to see such phenomenon from the perspective of political sociology. Bandar Lampung local election is one of the cases of simultaneous regional elections (pilkada) in December 2015. This paper reviewed the relationship between voters and candidate pairs in the 2014 Lampung Governor election compared to the case of the 2015 Bandar Lampung Mayor election.

Patron-client relations can be seen in the literature of the 1970 s as a characteristic of pre-industrial societies. One of the initial definitions was stated by Scott (1972: 92) who conceptually defined patronclient relations as:

'A special case of a two-person relationship involving friendship in which an individual from a higher socio-economic status (patron) uses his own influence and resources to provide protection or benefits, or both, for people who are of lower status (clients) reciprocate by offering support and assistance, including personal services or protection.'

This definition describes the asymmetrical relationship between patrons and clients. As it is explained by Lande (in Schmidt, 1977: xiii), client patron is a relationship consisting of only two people, thus means a micro-level entity. This personal bond must be based on mutual trust (Eisenstadt and Roniger, 1984). Tilly (2004) argues that this relationship refers to a basic unit such as social organization as network trust.

Patron-client in Scott's opinion (1972: 92) has several criteria as follows: First, there are inequalities in social status, which illustrate the differences in power, wealth, and position. The client is a person who enters an unbalanced exchange relationship; he/ she is unable to fully repay the patron, the debt of obligations bind him/her, and it is all depend on the patron. Second is the face to face process or direct meeting. The nature of this relationship is instrumental with both parties taking into account the profit and loss, while the element of taste remains influential because of the closeness of the relationship. Third, the bonds are flexible and widespread. The nature of widespread can be seen not only in work relations, but also in neighboring relationships and hereditary closeness or friendship. This type of exchange is not only involved money or goods, but can also be in the form of assistance, help, strength and support, and even protection.

According to Legg (1983: 29), the forming of patron-client relationships have several requirements to make the relationship intertwined: first, patron has mastered many and unlimited resources; second, the relationship between the two (patron and client) is personal: third, the decision to hold an exchange is based on mutual and beneficial understanding (symbiosis of mutualism).

The opinion expressed by Huntington (1984: 154) also reinforces the above definition that patron-client relations are tied individually and based on an unbalanced mutual exchange of benefits. Patrons of higher status provide protection, economic assistance, reflection of their status to their clients, and intervene on their behalf to connect with government officials. Clients reciprocate by giving them loyalty and respect, labor, small gifts at certain times, and political support.

Clientelism in the last decade was redefined, driven by the fact that it survived in developed countries by ignoring the government system (authoritarianism or democracy). Piattoni (2001) explains and observes how democracy actually strengthens the clients through bargaining process between brokers and customers. Clientelism is not destroyed by democracy and program platforms but is forced to develop into a network of exchanges with complex pyramids among clients, brokers, and patrons (Kitschelt and Wilkinson 2007: 8).

Hopkin (2001) has another opinion. He provides a newer definition of clientelism compared to Scott's. Hopkin states that clientelism involves many parties who share state resources for groups or individuals in an exchange and sometimes less uniform and less personal. This pattern of relations is more materialistic than the old definitions (Hopkin, 2001: 3).

Kitschelt and Wilkinson (2007: 4) propose a bit different definition. They argue that clientelism has developed into a more symmetrical (not asymmetrical) exchange relationship; it is rational (not normative) and mediated by a broker who do not do face to face process. Kitschelt and Wilkinson defines clientelism as direct exchanges or transactions of citizens in exchange for direct payments or rewards in 
the form of access to jobs, goods and services (Kitschelt \& Wilkinson 2007: 2).

This new meaning or definition provides three changes in the perspective of patronclient relations (Volintiru 2010). First, the mutual need relationship (symbiosis mutualism) between patrons and clients; they are the main suppliers of goods and services to the liaison (broker) to make transactions. Such condition describes a full scale of social hierarchy. Second, the earlier definition contributes to emancipation of clients since there is no asymmetrical relationship or dominance, but commercial transactions between one and the other offer what is desired. Unluckily, the fact is not always happen exactly the same as that second definition. It turns out that patrons and brokers have political or economic monopolies (Medina and Stokes, 2007), or at least are part of economic or political oligopoly. This fact shows that there is still an asymmetrical relationship in practice; therefore, client dependence remains significantly higher than that of patrons. Third, this new definition contributes to the need for intermediation in modern patronage networks; electoral clientelism requires a larger mobilization structure that can no longer be served by patron-client relations in the definition proposed by Scott (1972).

Patronage or clientelism is a concept of power that is born from an unbalanced relationship between patrons in one party and the client on the other. This imbalance basically relates closely to unequal ownership of resources in society. Therefore, in that phenomenon, the interrelation has been bound by interests and manipulated by their respective goals, even though both are in an unbalanced position (Agustino, 2014: 173). Patronage or client buying is a profit sharing among politicians to distribute something individually to voters, workers or campaigners, in order to get political support from them (Shefter 1994: 283 in Aspinall, 2015: 4).

Patronage can be interpreted as giving cash, goods, services, and other economic benefits (such as jobs or project contracts) by politicians, including direct benefits to certain individuals (for example, giving them envelopes of money/cash) and to groups/communities (for example, granting a new soccer field for young people in a village) (Aspinal \& Sukmajati, 2015: 4). Patronage can also be in the form of cash or goods distributed to voters which come from personal funds (for example in the purchase of votes) or from public funds, for example the pork barrel projects. Patronage refers to material or other benefits distributed by politicians to voters or supporters, whereas clientelism refers to the character of relations between politicians and voters or supporters (Aspinall \& Sukmajati, 2015: 4).

In practice, patronage is an act of favoritism in the interaction of someone with various parties, inside and outside the organization. There are similarities between patronage and nepotism, in the sense that the criteria used in enforcing other people are not rational and objective, but rather subjective. These subjective criteria can be based on primordialism, such as ethnicity or regionalism, or other considerations. It can also be caused by similarities in ministries and hobbies outside of services (Siagian, 1994: 58).

Politicians use government-owned resources and distribute them to voters by conveying political messages that the program is funded by private sources. Politicians of the ruling party may not manipulate social programs financed by the state and distribute them to voters as personalized public goods, and then use it as a medium to buy votes (Desposato 2007).

Personalization of public goods is done through credit claiming for the distribution of goods or other material. By doing so, politicians can make political statements that the government programs are the result of their efforts, a form of their hard work. As political claims, the politicians want to state that the realized policies or programs are the result of individual efforts and not the result of political parties achievement or government performance (Mayhew, 1974).

Political claim refers to an act carried out by politicians to gain voters' trust that they are working personally and push the government to produce outcomes or programs desired by voters; and political claims become one way to fulfill an election (Mayhew, 2008).

Political claims are very important so that many politicians who do not have any contribution in the realization of a program or policy state their political claims by saying they have also worked hard and done sincere efforts (for the program or policy). This mutual claiming ultimately leads to the emergence of polemic or even political conflict between politicians. Political claim basically has two 
functions: first, it serves as instrument for personalizing public goods; second, it also functions as a tool to bind voters who, in this case, also recipients of the program which expected to give their political support to the politicians who do political claims (Sumarto, 2014: 35).

\section{Research Methods}

This study is qualitative research which sees most social life as intrinsic case. Lawrence Neuman (2006: 157) defines qualitative research as:

"Qualitative researchers use a language of case and context, employ bricolage, examine social processes and their social contexts, and look at interpretations or meaning settings. They look at social life from multiple points of view and explain how people construct identities. Only rarely do they use variables or test hypotheses, or convert social life into numbers."

Most studies use grounded theory. This is what makes research have flexible and more interesting data. According to Harper and Schwandt in Lawrence Neuman (2006: 157), qualitative research remains open to change; qualitative research is willing to change the direction or focus of research projects and may leave their original research questions in the middle of their research projects. Case studies according to Neuman (2006: 40) can be done by individuals, groups, organizations, interest groups, events, or units based on geographical location.

The data source in this study comes from primary data, sourced directly from field research through interviews with voters and political brokers. This data is in the form of interviews and documentation obtained by researchers when the research takes place.

Other data comes from secondary data, sourced from library in the form of supporting materials and/or information obtained from third parties related to the problem under study, such as books, regulations, documents, and laws.

To collect data in this research, researchers used three techniques of field data, in-depth interview, and library study.

This research focused on patron-client relations and its dynamics in local politics in Lampung, which was divided into two case studies: 2014 Governor of Lampung Election and 2015 Bandar Lampung Mayor Election.

\section{The Pattern of Patronage in Lampung Governor Election}

Study from Ward Berenschot (2014) explains the pattern of clientelisms in 2014 Lampung Governor Election. Financial support from Sugar Group Company (SGC) allows Ridho (the candidate) to carry out any activities he considered necessary. He put his pictures on many sugar sacks and decorated them with musical instruments. He also distributed qurban meats of cow and goat during Eid alAdha, and held an event of shadow puppets with ultimate prizes of motorcycles and other prizes for lucky audience. Based on the study, there was a possibility of certain amount of money distribution activity. 44 percent of the vote won by M. Ridho Ficardo-Bachtiar Basri and beat the other pairs. The costs incurred for the winner were estimated up to 500 to 600 billion rupiahs.

SGC has a considerable role in local politics. The company has provided a lot of assistance since 2011 to politicians and local officials. SGC has also helped the regent's election campaign funds, especially in Tulang Bawang and Tulang Bawang Barat districts.

Tulang Bawang and Tulang Bawang Barat districts have extensive sugar cane fields owned by SGC leader Mrs. Lee Purwanti. Officials and politicians as well as stakeholders are those who helped this company multiply their profits. The main reason for SGC to control the land is the termination of 30-years land leases with the right to cultivate land (HGU) for several SGC's plantations.

The conflict interest of SGC also involved other company owned by Salim group, many parties from the community, officials of land lease, and ownership of the sugar cane factory. This 'battle' won by SGC through collusion with local officials and politicians. The Tulang Bawang community in 2012 voiced their land rights seized by the SGC, but their voices were silenced by SGC supporters and sympathizers.

SGC's needs for land or plantation land, especially sugar cane fields, along with factories to produce sugar and cheap labor, are well utilized by both local and executive authorities. Financial approach with mutual benefits between the two parties makes SGC willing to pay dearly to bribe local officials. The business calculations of SGC officials were very pragmatic. They realized that they needed political contact to obtain land licenses and eliminate illegal levies. 
Those considerations eventually encouraged SGC to plunge into practical politics by supporting certain politicians. The elected politician was a charismatic young figure, M. Ridho Ficardo, who also happened to be a biological child of Fauzi Thoha, a principal manager of SGC Company.

Researchers' observation on campaign pattern in Lampung Governor election, April 2014, found the common sight of vote buying phenomenon. People asked for compensation (money) to politicians. They were not satisfied with the electoral process and major primary needs of fostering patron-client relations. It was well captured by Ridho as a governor candidate at the time by creating the right image of young, energetic, and rich. Public can see the involvement of SGC Group in 2014 Lampung governor election by the relations shown between Mrs. Lee Purwanti, Fauzi Toha, and M. Ridho Ficardo (Berenschot \& Purba, 2014).

In addition to strong financial involvement from SGC, Ridho's victory was also supported by networks or brokers who work very hard to reach their goals. They were highly paid with fantastic amount of money. Political brokers confessed that before joining the brokerage they could only have a second-hand motorcycle to get around the village, but after the election they can replaced it with a new car. On the other hand, broker network is obtained by kinship networks or parties which considered relatives or close friends. Ridho's political broker was selected in such way with a mature strategy where the information obtained usually went through the word of mouth and confidential.

Political broker in Lampung Governor Election has its own stages and levels which can be varied from one to three stages. The money which sourced from first hand can be either directly distributed to voters or passed to the next stages of second hand to third hand and ended up to voters.

Figure 1 explains that in a matter of business interests, especially in terms of management and control of sugar cane plantation, SGC competes with Salim group. In order to win the business competition, SGC carried out patronage practices by providing campaign assistance to many local politicians in local election. Provision of campaign funds sourced from the profits of sugar sales has been carried out since 2011, particularly in the elections of Tulang Bawang and Tulang Bawang Barat districts. The success they have had inspired the SGC to participate in 2014 Governor Election by promoting and supporting $M$. Ridho Ficardo, the son of Fauzi Thoha, one of the main managers in SGC company.

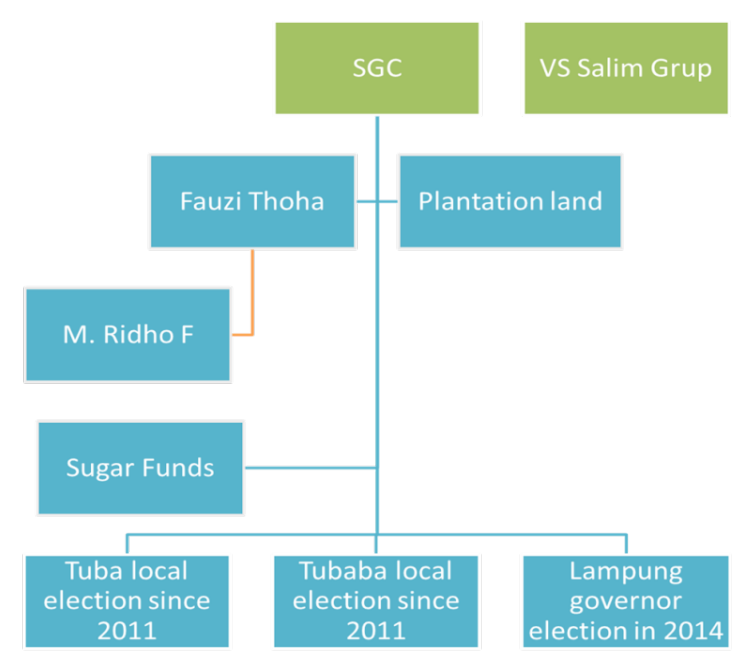

Figure 1. The Pattern of Patronage in Sugar Group Company (SGC)

Source: Berenschot \& Purba (2014)

The previous author's research on vote buying can help explain the phenomena of patronage patterns occurred in 2014 Lampung governor election. Vote buying in regional head elections based on the research results conducted in Way Kanan district and Pringsewu district can be caused by: first, voters were still hesitant about their choices and waiting for what the candidates would give them; second, the habit of giving gifts or souvenirs from candidates who will compete in the elections has formed some kind of traditional cultural courtesy; third, voters who worked mostly as farmers and cultivators felt that their working time has been stolen and thus affected their income. They thought it was considered reasonable if they were received a substitute of money or goods if they participated in the campaign or attended the election day to vote. Voters expected something useful (money or goods) as a return for their political support.

The low social and economic status of voters was the last thing which caused a vote buying occurred at research location. Areas of low income or population with less income were usually targeted for vote buying practice. In cases of Way Kanan and Pringsewu district, voters were mostly 
farmers and the shift in their political choices (to vote) was largely determined by money or goods they would receive as a return of their votes (Kurniawan, 2017; p 366).

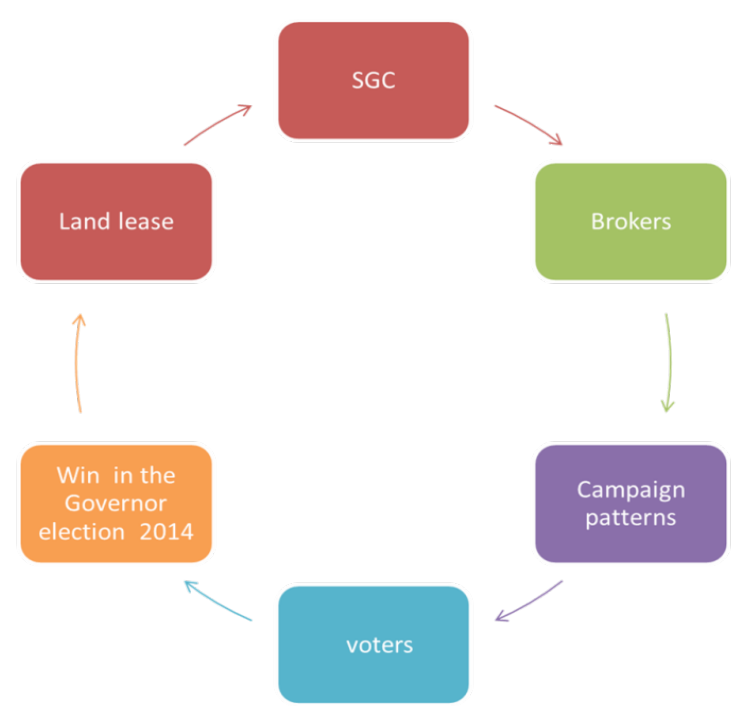

Figure 2. The Pattern of Patronage in Lampung Governor Election

Source: Data Processed in 2015

Figure 2 describes the flow of patronage patterns in Lampung Governor election in 2014, Sugar Group Company (SGC) hired or provided brokers for the M. Ridho Ficardo campaign to influence voters. While Ridho won the election, the benefits obtained by SGC were that the land lease plantation in Lampung was extended again.

\section{The Pattern of Patronage in Banda Lampung Local Election 2015}

Incumbent Mayor of Bandar Lampung, Herman HN, has his own network in new mayor election of Bandar Lampung. The winning team reported to Bandar Lampung Commission of Election (KPUD) who served as the Liaison Officer ( $L O$ ) consisted of three people (later called the team of three) namely Rahmat Husein DC, Resmen Khadafi, and Aryanto Yusuf. All of them were directly chosen by Herman HN without the involvement of Yusuf Kohar as his vice mayor. Yusuf Kohar was just acknowledged it and agreed.

The task of the team of three, in particular, was the thinker and formulation team covering the whole contents of speech, preparation of campaign material, and the approach to constituent pattern even to legal assistance in the case of alleged reports in the elections. The three team also had the authority and freedom to shift from the field of implementation to evaluation activities. They coordinated directly with Herman HN and had their respective duties and work specifications.

"(The team consisted of) Aryanto and Khadafi, because Khadafi has no burden (or bad record) at previous winning. The result of the discussion was equally true. Mr Herman HN was a candidate, but he even wanted to do his own speech because we are considered at the same level... Khadafi deals with legal matters, I deal with politics and it deals with people's affairs. Ariyanto has the ability to communicate with the organizers ... I will cover issue of Herman HN. I divided up matters in which Khadafi takes care of legal matters while Hariyanto does the communication with the organizers, for example, with the KPU if I fill out the campaign for Pak Herman HN " (Source: Interview with Rahmat Husein, October $\left.12^{\text {th }}, 2016\right)$.

The team of three, which was the core team of the winners and officially reported to Bandar Lampung Commission of election (KPUD), had another escort team which was not officially registered in KPUD. The companion team was divided into several coordinators, namely the subdistrict level coordinator, kelurahan (urban village) level coordinator, and the neighborhood unit coordinator (RT). The task of each of these coordinators was to prepare the stage and gather the voters/communities. For operational activities, each urban village coordinator received funds for two million rupiahs in total to provide food and drink for the masses.

"There are coordinators that we did not register in KPU because we want to prevent the possibility of something bad happen later, such as a sub-district coordinator do the betrayal for the basic needs, so we avoid a coordination through cellphone phone and arrange direct meetings instead. The task coordinator prepare the stage. In 20 sub-districts we have counted 1 meeting for 3000 rupiahs with the kanopi (tarup) and all kinds of results, for example, 1 urban village receives 2 million. 1 sub-district, let us say, consists of 7 sub-districts, then the district coordinator holds 14 million rupiahs for that purpose. One campaign point is 2 million rupiahs."

(Source: Interview with Rahmat Husein, 12 October 2016). 
The team of three was given individual operational funds for a week with the amount ranged from five hundred thousand rupiahs to one million rupiahs. The funds were used for field operations, starting from gas (fuel) cost, phone bills/cellphone pulse bills, as well as food and drink cost. Operations for mass collection are left to the subdistrict coordinator, depending on the number of villages in the sub-district, so that field operational was funded to collect different masses in each sub-district. After mayor election had finished, the team of three was awarded (by Mayor (Herman HN) the position of expert staff in Bandar Lampung City with a monthly salary of seven million and five thousand rupiahs.

"Our operational cost per week is 500 thousand -1 million rupiahs ... If experts are too busy and I want to meet the principle, he is there for me". (Source: Interview with Rahmat Husein, 12 October 2016).

The team of three also functions as a liaison for both internal and external affairs. External liaison coordinated with Bandar Lampung Commission of Election, Election Supervisory Body (Panwaslu), police (Polres), Gakkumdu and all other external matters. As internal liaison, team three coordinates with witnesses, the campaign team, and candidates.

"When talking about another team (sure) there is. We can't get $86.6 \%$ with the efforts of only 3 people. This means there is a campaign team and a witness team and we communicate with each other. There are 3 witnesses from each of our sub-districts with 2 witnesses in every polling station, so that all witnesses carry out the task in collaboration with stretcher party who works from coordinator of communication."(Source: Interview with Resmen Khadafi, 21 Oct 2016).

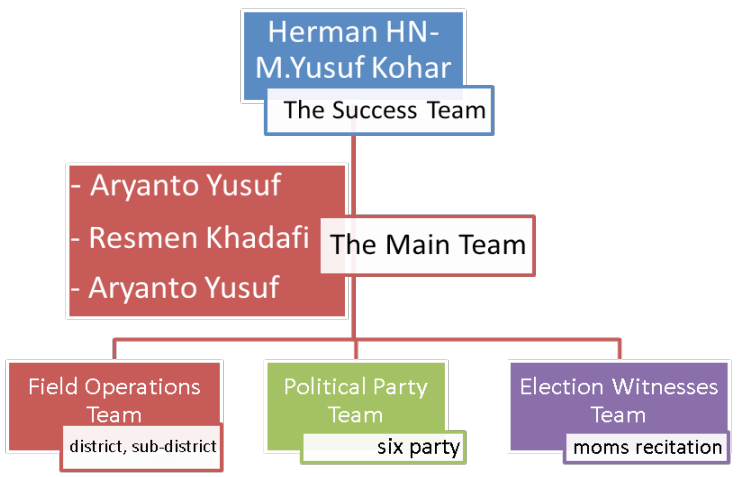

Figure 3. The Success Team of Herman HN-Yusuf Kohar
Figure 3 is a structure of winning team of Herman HN -Yusuf Kohar, compiled from the result of interviews. Most of the personnel in the structure were non-government (civil) selected by Herman HN. The main team, a team of three which serves as Liaison Officer (LO), appointed by Herman HN -the incumbent mayor- based on his personal closeness. The three have already collaborated with Herman $\mathrm{HN}$ before during his first term as a mayor in the period of 2010-2015.

Team of three (Rahmat Husein, Resmen Khadafi, and Aryanto Yusuf) are close friends of Herman HN and were given the responsibility as experts staff in Bandar Lampung City with a salary of seven million five hundred thousand Rupiah per month before they officially became LO. They resigned after appointed as LO and resumed their position after Herman HN-Yusuf Kohar won the election and officially stated as new mayor and deputy mayor.

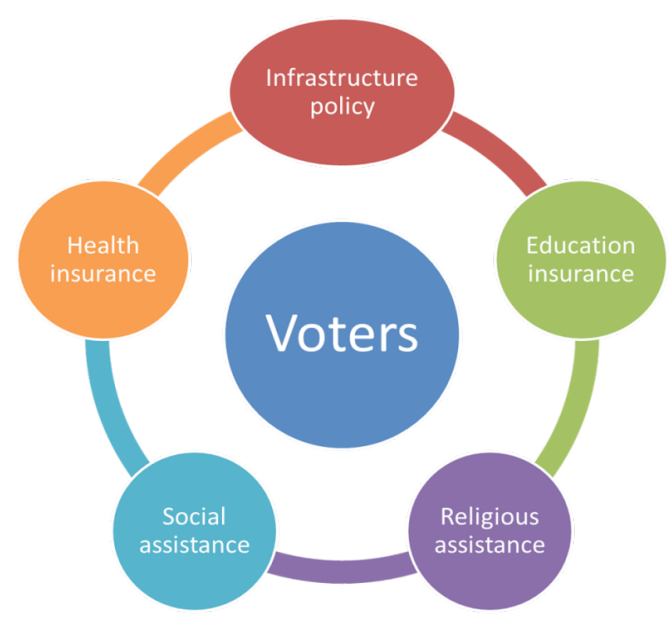

Figure 4. Herman HN: The Pattern of Clientelism to Voters

Source: 2016 data processed

Figure 4 explains that the pattern of clientelism used by Herman $\mathrm{HN}$ to maintain the quantity of political support from voters of Bandar Lampung City can be divided into four types of main programs in accordance with his campaign promises both in the initial period of the 2010 term and when he won Bandar Lampung local election in 2015. The four types of patterns used were infrastructure development, particularly roads and flyover in the city; provide regional health insurance in the form of health cards apart from Jokowi's program (BPJS and KIS); the provision of free education at elementary, junior, and senior high school through community development 
programs; social and religious assistance (in funeral procession or marriage); assistance for religious teachers; and do umrah (little hajj) together.

One important relation noticed in the pattern of patron-client and exchange theory, based on the explanation above is the element of exchange. The exchange relationship is quite real between patrons who provide protections and clients who provide supports, so that it can be concluded that the pattern of patron-client relations can be incorporated into broader exchange relations, namely exchange theory. Linkage drawn between patron-client relationships and the theory of exchange, although the exchange occurs in an unbalance pattern (the dependence of client to patron), is appropriate to be drawn together in the exchange of dependency theory (Muslim, 2015, p. 463)

The basic relationship in patronsclients model of relations occurs because patrons provide assistance to their clients (those who have limited economic life or low income). Therefore, the relationship between patrons and clients is lasting quite long because patrons can always cover the basic needs of their clients. This dependency creates a strong relationship between the two parties. Meanwhile, it is different in the master-servant relationship where relations occur because of submission and servant's submission to the excess abilities possessed by the master. The basis exchange in patronclient relations is something concrete, that is, the patron provides assistance in the form of money or goods and the client reciprocates with the same thing, or sometimes in the form of services. Whereas, in the masterservant relationship, the basis exchange is relatively vague in which the servant will give all his efforts sincerely for his masters with the hope they would sincerely give knowledge and abilities to the servant (Muslim, 2015, p. 471)

\section{Conclusion}

The relationship between patronsclients in the 2014 Lampung Governor election occurred in the candidate governor of M. Ridho Ficardo-Bachtiar Basri. The pair won the election by the help (mutual cooperation) of SGC (Sugar Company) to buy voters through fantastic campaign programs. A campaign program in the form of traditional puppets events (wayang kulit) is accompanied by attractive prizes of motorbikes and other luxurious items. Election Supervisory Agency of Lampung (Bawaslu, Panwaslu) found sugar distribution in several places. Although it cannot be proven in Gakkumdu, there was a strong evidence that the company involved in winning one governor candidate. Community reports collected by the election supervisory body (Panwaslu) had no effect in Gakkumdu because the absence of the evidence.

The pattern of patronage in 2014 Lampung Governor Election showed that the SGC used brokers to organize and manage voters with high-cost political imaging. The popularity of candidates from SGC increased significantly with imaging patterns of wayangan events (traditional puppets and giving prizes which made $M$. Ridho $\mathrm{F}$ won the election. Whereas the benefit for SGC was the extension of plantation land lease in Lampung Province.

Herman $\mathrm{HN}$ winning in Bandar Lampung local election in 2015 was obvious and quite smooth since he had already invested his political capital when he first served as mayor in 2010. Herman HN victory showed the success of politic imaging in the community, as well as his successful performance shown during his tenure as mayor which gained voters' trust and made them choose him.

Herman HN's patronage pattern in the 2015 Bandar Lampung Mayor election, in addition to the using of pro-voter policies namely free health, free education, social religious assistance, and infrastructure policy, was also the work and influence of a solid winning team. Herman HN successful teams were at all levels of society, consisting of field operation team, political parties, and teaching team.

A suggestion from the author is to limit the space and involvement of companies or corporations as well as political brokers in local elections, particularly in Lampung to audit campaign funds and company donations. Voters must be aware that the patterns of clientelism, even though on the basis of mutual benefit, undermine the foundations of democracy and resulted in the emergence of money politics which endanger the mindset of voters.

\section{References}

Agustino, L. (2014). Politik Lokal dan Otonomi Daerah. Bandung: Alfabeta 
Aspinall, E., \& Sukmajati, M. (2015). Politik Uang di Indonesia, Patronage dan Klientelisme pada Pemilu Legislatif 2014. Yogyakarta: PolGov UGM

Berenschot and Purba (2014) (http://www. insideindonesia.org/pemilu-lampungyang-berlapis-gula), diakses 18 Februari 2015

Desposato, S. W. (2007). "How does Vote Buying Shape the Legislative Arena?", in F.C. Schaffer (ed), Election for Sale: The Causes and Consequences of Vote Buying, Lynne Rienner Publishers, Boulder, pp. 101-122

Eisenstadt, S.N. and Roniger, L. (1984) Patrons, clients and friends: Interpersonal relations and the structure of trust in society, Cambridge University Press

Hopkin, J. (2001). A "Southern model" of electoral mobilization? Clientelism and electoral politics in post-Franco Spain. London: LSE Research

Huntington, S., P. (1984). Partisipasi Politik di Negara Berkembang, Jakarta: Sangkala Pulsar

Kitschelt, H. and Wilkinson, S.I. (2007). Patrons, Clients, and Policies: Patterns of Democratic Accountability and Political Competition, Cambridge University Press

Kurniawan, R., C., Mudiyati, R., Agustino, L. (2017). "Vote Buying in Lampung Local Election", Jurnal MIMBAR Unisba, Volume 33 No 2 (Desember 2017) pp 359-367.

Legg, K., R. (1983). Tuan Hamba dan Politisi. Jakarta: Sinar Harapan

Mayhew, D.R. (1974). Congress: The Electoral Connection, Yale University Press, New Haven.

Mayhew, D.R. (2008). Parties and Policies:
How the American Government Works, Yale University Press, New Haven

Medina, L. F. and Stokes, S. (2007). Monopoly and monitoring: an approach to political clientelism in Patrons, Clients, and Policies: Patterns of Democratic Accountability and Political Competition, ed. H. Kitschelt and S. Wilkinson. Cambridge: Cambridge University Press.

Muslim, A., Kolopaking, Dharmawan, and Soetarto. (2015). "Dinamika Peran Sosial Politik Ulama dan Jawara di Pandeglang Banten". Jurnal MIMBAR Unisba, Vol. 31, No. 2 (Desember, 2015): pp 461-474

Neuman, L. (2006). Social Research Methods. USA: University of Winconsin at Whitewater

Piattoni, S. (2001). Clientelism, Interests, and Democratic Representation: The European Experience in Historical and Comparative Perspective, Cambridge University Press

Schmidt, S., W., Scott, J., C., Lande, C., Guasti, L. (eds.) (1977). Friends, Followers and Factions: A Reader in Political Clientelism, University of California Press

Scott, James C (1972). Comparative Political Corruption, New Jersey, Prentice-Hall.

Siagian, S., P. (1994). Patologi Birokrasi, Analisis, Identifikasi dan Terapinya. Jakarta, Ghalia Indonesia

Sumarto, M. (2014). Perlindungan Sosial dan Klientelisme, Makna Politik Bantuan Sosial dalam Pemilihan Umum. Gadjah Mada University Press.

Tilly, C. (2004). "Trust and Rule', Theory and Society, 33:1, pp: 1-30

Volintiru, C. (2010). "Clientelism and Democratic Accountability". PSA Graduate Network Conference, December 2010. 